\title{
Cultures, languages, Nations: Conceptions AND MISCONCEPTIONS
}

\author{
Kenneth McRoberts
}

It has become a commonplace that the nationstate is dead - or at least is in mortal danger. Its capacity as a state has been severely eroded by the forces of globalization and regional integration: supra-national organizations and global corporations have assumed powers and prerogatives which, within the nation-state ideal, belong to the state.

But the nation-state has lost more than its state; it has also lost its nation - in part because of these very external forces. Whereas the nationstate ideal presumed that a single national language would prevail throughout its territory, languages with deep historical roots have reappeared within the same state. In some cases, this has involved the revival of long dormant languages - as in Wales or Scotland - but in other cases it has meant the return to public space of languages that had been excluded, indeed banned, as was Catalan under the Franco regime. In some settings immigration has served to break the national language's monopoly by reinforcing other languages, as in the United States, where Spanish has gone from being a marginal, and essentially private language, to a major one that is increasingly intruding into the public realm despite the erstwhile efforts of some English-only advocates to keep it out.

The nation-state was supposed to have a single national culture. Yet, virtually all of the self-styled nation-states, whether France or the United States, are increasingly preoccupied with the cultural diversity that manifestly exists among their citizens and are actively debating formulas such as multiculturalism, interculturalism and so on.

Finally, direct challenges to the very title of "nation" have emerged from within nation-states, whether from indigenous peoples, as in the United States or Mexico, or from longstanding populations which never had accepted the pretensions of nation-state but are now better placed to make their opposition known, such as the Basques or the Catalans.

In short, after dominating so much of recent Western history, the notion that states should be nations and, as such, should have a single language and a single culture, seems to have lost most of its driving force.

For its part, Canada managed to avoid this illfated struggle to construct a nation-state - at least until recently. Coming late to the struggle, it has tried to build a nation-state with a difference - one with two national languages. Yet, for all its originality, this effort has been no more successful than the others. Indeed, in the case of Canada it has served to bring the state to the brink of collapse.

Historically, Canada did not qualify as a nation-state and most Canadians seem to have accepted that. Clearly, Canada did not have a single national language. At the time of Confederation in 1867, about 70 percent of the population spoke English and 30 percent French. ${ }^{1}$ In the new province of Québec, people of French

This article is largely based upon "Cultures, Languages and Nations: conceptions and misconceptions," paper presented to the Sixteenth Annual London Conference for Canadian Studies, Birkbeck College, University of London, February 26, 2000.

1 According to the 1871 census, 60.5 percent of Canadians were of British origin, with 3.1 percent of French origin and 8.4 percent from other groups (Charles Castonguay, "The fading Canadian duality" in John Edwards, ed., Languages in Canada (Cambridge: Cambridge University Press, 1998) at Table 2.1). 
descent constituted about 78 percent of the population. ${ }^{2}$ In the other provinces, they were small minorities: 16 percent in New Brunswick, 4.7 percent in Ontario and 8.5 percent in Nova Scotia. $^{3}$

At the time, it was also generally recognized that with language came culture. Nor was there much difficulty in identifying the terms of the cultural divide between Anglophones and Francophones. Difference in predominant religion was a good starter, but people had no trouble discerning many other differences as well.

Francophones tended to see themselves as constituting a distinct nation within Canada. Their leaders had adopted the very term in the 1820 s, to denote the nation canadienne. As Anglophones increasingly appropriated the term 'Canadian' for themselves as well, Francophones turned to the idea of a nation canadienne-française. Under the clerical and conservative leadership that had become dominant within French Canada by the time of Confederation, there was no question of the nation canadienne-française becoming a fullfledged nation-state of its own. Indeed, in the Church's eyes, states of all kind were quite suspect. But there was also no doubt that Francophones constituted a nation.

For their part, English-speaking Canadians tended to see themselves as members not of a nation within Canada, or even a nation that was coterminous with Canada, but of a much larger entity. They were people of British nationality who were creating a British nation in Canada and were remaining integrally part of the British Empire. In one of Sir John A. Macdonald's oftquoted phrases, the new Canada was to be "a British nation, under the British flag and under British institutions."

Out of these circumstances emerged a political practice and tradition that could accommodate, if not explicitly recognize, these differences. Canada

\footnotetext{
Richard J. Joy, Languages in Conflict (Toronto: McClelland \& Stewart, 1972) at 91.

See Richard J. Joy, Canada's Official Languages: The Progress of Bilingualism (Toronto: University of Toronto Press, 1992) at 71, 93 and ibid. at 77.

4 As quoted in P.B. Waite, The Life and Times of Confederation, 1864-1867, 2d ed. (Toronto: University of Toronto Press, 1962) at 22.
}

was not formally binational. Nonetheless, its founding document, the British North America Act, $1867,{ }^{5}$ guaranteed a certain status for French along with English in the federal Parliament and courts, as well as in the province of Québec. Moreover, the principle of federalism was adopted precisely because of the concerns of FrenchCanadian leaders that the interests of their nation would be subordinated to those of Anglophones who would be the overwhelming majority within the new Canadian government. Indeed, the rhetoric of the time could not have been more explicit as to the importance of federalism to preserving the French-Canadian nationality - to quote La Minerve, a leading Blue newspaper, "[i]n giving ourselves a complete government we affirm the fact of our existence as a separate nationality, as a complete society, endowed with a perfect system of organization." "' Indeed, on the day of the Confederation's birth, the newspaper declared that "[a]s a distinct and separate nationality, we form a state within the state. We enjoy the full exercise of our rights and the formal recognition of our national independence."7 Apparently, the very choice of "Confederation" to denote the new political arrangement was a deliberate attempt to find a term, however misleading, that would placate the desire of French Canadians to enjoy maximum autonomy.

During the early decades of Confederation, the federal principle took root among Anglophone Canadians as well. Political economy and partisan rivalries combined to make the Ontario government a leading champion of provincial rights, especially under the leadership of Premier Oliver Mowat. Mowat joined with Québec premier Honoré Mercier, to organize the first interprovincial conference, held in Québec City in 1887. At the conference, the assembled premiers, who came from all but Conservative-controlled British Columbia and Prince Edward Island, not only called for constitutional changes to limit the federal government's powers, but celebrated the theory that Canada itself was based on a compact among the several colonies from which it was derived. According to this compact theory,

\footnotetext{
(U.K.), 30 \& 31 Vict., c. 3.

As quoted in A. I. Silver, The French-Canadian Idea of Confederation, 1864-1900 (Toronto: University of Toronto Press, 1982) at 41 [emphasis added]. Ibid.
} 
developed by the Québec judge T. J. J. Loranger, the constitution could not be changed without the consent of all the successors to the original colonies, the provincial governments. ${ }^{8}$ By the end of the nineteenth century, virtually all prominent politicians, Anglophone as well as Francophone, endorsed the compact theory of Canada.

For Francophones, however, the notion of provincial rights was a double-edged sword. In the hands of Anglophone-dominated provincial governments, it could be used to legitimize actions that suppressed the linguistic rights of their Francophone minorities. Indeed, during the first few decades, most provincial governments, other than Québec, acted in precisely this fashion. Accordingly, at the turn of the century a leading French-Canadian nationalist, Henri Bourassa, developed a new version of the compact theory of Canada. According to Bourassa, there was a double compact: a political contract among the colonies and their provincial successors, and a national contract between the Anglophones and Francophones. ${ }^{9}$ While this national contract had originated in the United Canadas, Bourassa argued that it extended throughout the new Canada, including the new territories to the West. For Bourassa, this second contract did not replace the one among the provinces. The province of Québec had a special importance as the "particular inheritance" of French Canadians. The two contracts were to remain together in an uneasy coexistence.

To be sure, there was a tension here. English Canadians subscribed only to the first notion of a compact, namely the one among provinces, and had little patience for the notion of a compact between French and English, assuming that they had even heard of it. French-Canadian attachment to the notion of a compact among the provinces was essentially focussed on the province of Québec. Québec's autonomy was precious, not

\footnotetext{
T. J. J. Loranger, Letters Upon the Interpretation of the Federal Constitution Known as the British North America Act, (1867) (Quebec City: printed at the Morning Chronicle office, 1884). See also R. Cook, Provincial Autonomy, Minority Rights and the Compact Theory, 1867-1921 (Ottawa: Queen's Printer, 1969) at 29-31.

9 Henri Bourassa, Le Patriotisme canadien-français: ce qu'il est, ce qu'il doit etre: discourse pronounce au Monument National, le 27 avril 1902 (Montreal: CIE de Publication de la Revue canadienne, 1902) at 8, as translated and quoted in R. Cook, ibid. at 57.
}

simply because it was a successor to one of the British colonies, but because it was the heart of French Canada. It continued to be the only province with a French-Canadian majority. In the words of La Minerve, it was the home of a "separate nationality." 10

Nonetheless, neither notion of a compact, whether it was among colonies or between nationalities, was compatible with the idea of a nation-state. English Canadians may have rejected the idea of a binational Canada, but as long as they understood Canada to be a compact among all the provinces, the federal government could not be the state of a Canadian nation. It was simply "the federal government," or maybe the "Dominion government," but not the "national government."

External developments, most particularly the experience of two world wars, led Anglophone Canadians to begin to develop the notion of a Canadian "nation" that was not simply a projection of a British nationality. Moreover, in the wake of the Second World War, the federal government began to present itself as a "national" government, undertaking a series of measures, such as the creation of the Canada Council, to support the development of a "national" culture. It also created a welfare state to ensure that all Canadians, as members of the Canadian nation, would enjoy certain basic services whatever may be their province of residence.

Yet, these notions did not take in Quebéc. During the two wars, most French Canadians resisted the notion of conscription for overseas service, seeing in it a continued subservience to Britain. Moreover, the federal government's postwar intrusions into provincial jurisdiction, in the name of the Canadian nation, were stoutly resisted by the Duplessis government with the clear or grudging support of most of the French-Canadian political and intellectual leadership.

With Québec's Quiet Revolution in the 1960s, pressures developed for a much more explicit recognition of the original notions of Canada as a compact, both between Anglophone and Francophone nations but also among the provinces, or at least with the Province of Québec.

\footnotetext{
$10 \quad$ Supra note 6.
} 
Within French Québec, an old middle class of liberal professionals, coupled with the clergy, had lost hegemony to a new middle class of salaried professionals. This new middle class had arisen largely from within Church-related organizations that continued to provide education and social services to Québec's Francophones. During the 1950 s, this class was leading the call for an expansion in the functions of the Québec government to raise the general welfare of Francophones but also to open up opportunities for Francophones in the Québec economy, where ownership was largely in English-Canadian and American hands and management positions tended to be held by Anglophones. Joining them were leaders of Québec's union movement, especially the Confédération des travailleurs catholiques du Canada (CTCC), which was largely restricted to Québec Francophone workers. With the election of the Liberal Party under Jean Lesage in June 1960, the new Francophone middle class was able to exercise a new influence within the Québec government. Indeed, rapid expansion of the Québec state provided a new base for its members. For its part, the CTCC had become the Conféderation des syndicats nationaux (CSN), and it pushed the Lesage government into a reformist direction with considerable success.

Out of these processes, the old idea of a French-Canadian nation was soon replaced with the idea of the nation of Québec. Only in Québec, it was argued, was there a Francophone majority. Thus, only in Québec could a modern society function fully in French. The continued assimilation of Francophones outside Québec was proof of that. The Québec provincial government would have to be a "national" government indeed, the state of the Québec nation.

Starting in the 1960s, young Francophones began to view themselves not as French Canadian, let alone simply Canadian, but as Québécois. Yet, they were not exclusively Québécois either. There was too much of a common past for that. Even now, most Québec Francophones see themselves as Canadian, but as a secondary and more purely political identity. Their national identity is as Québécois.

During the 1960s, the federal political leadership sought to find formulae and approaches to accommodate this national affirmation in Québec. In the course of this decade, leaders of all three parties explicitly recognized the presence of a Québécois or Francophone nation within Canada and approved measures, such as an asymmetrical federalism, to accommodate the desires of the Québec government, as a national government, to assume responsibilities that were exercised by the federal government in the rest of Canada.

Moreover, the Liberal government of Lester Pearson established a commission, the Royal Commission on Bilingualism and Biculturalism, with a mandate to "report on the existing state of bilingualism and biculturalism in Canada and to recommend what steps should be taken to develop the Canadian Confederation on the basis of an equal partnership between the two founding races ["peuples fondateurs"], taking account of the contribution made by other ethnic groups to the cultural enrichment of Canada." 11

Now, three decades later, the Commission has been largely forgotten. Yet, it seems to me that in its report the Commission offered an understanding of Canada in which especially language, but also culture, is properly situated within its social context. The vision that emerges is not that of a nation-state but of a Canada which is indeed truly bilingual and bicultural. I believe that much of Canada's present-day difficulty stems from the failure to appreciate the Commission's insights and to seek to render language and culture compatible with the goal of a single Canadian nation.

The Commission's structure closely reflected its mandate to explore Canada's linguistic and cultural duality. It had co-chairs, an Anglophone and a Francophone. The latter, André Laurendeau, was the leading French-Canadian journalist of the time and a major figure within French-Canadian nationalist circles. Laurendeau was the spiritual leader of the commission. Indeed, his conception of language, culture and Canada largely shaped the Commission's deliberations. The committee had eight other members, four Anglophones and four Francophones. It must be said that only two

\footnotetext{
11 Canada, Royal Commission on Bilingualism and Biculturalism, Preliminary Report (Ottawa: Queen's Printer, $1965)$ at 151.
} 
members were of non-British, not-French origin - once again, one was mainly Anglophones and the other was mainly Francophone.

At the beginning of the first Book of its Report, in several pages called "the blue pages" in which it outlined how it intended to interpret its mandate, the Commission succinctly presented its vision of Canada. There, the Commission was very clear that bilingualism was a state that existed in Canada as a whole, not with individual Canadians, stating that " $[\mathrm{w}] \mathrm{e}$ know that complete bilingualism — the equal command of two languages - is rare and perhaps impossible."12 Thus, if Canada is bilingual it is because it contains within it two linguistic communities. Nor is it the responsibility of the Canadian government to propagate individual bilingualism because "if everyone in a bilingual state becomes completely bilingual, one of the languages is rendered superfluous" and will disappear. ${ }^{13}$ Thus, in interpreting its mandate to enquire into the state of bilingualism in Canada, the Commission focussed not on individual bilingualism but the state of English and French "each being considered by itself" since "the question of the life and vigour of each language must have priority." 14 And, of course, it found that French was the language whose "life and vigour" was deficient in much of Canada. And while it was concerned with the strength of Francophone communities throughout Canada, the Commission fully recognized that Francophone life was largely concentrated in Québec. Indeed it declared that it recognized "the main elements of a distinct French-speaking society in Québec."15

On this basis, the Commission recommended that the de facto equality of English and French that then existed in Québec's political institutions should be made the formal model for two other provinces, Ontario and New Brunswick, but only those provinces. Otherwise, it proposed that within provinces particular census tracts, characterized by a significant presence of

12 Canada, Royal Commission on Bilingualism and Biculturalism, General Introduction (Ottawa: Queen's Printer, 1967) at xxviii.

13 Canada, Royal Commission on Bilingualism and Biculturalism, Book I: The Official Languages (Ottawa: Queen's Printer, 1967) at 12.

14 Supra note 12 at xxviii.

15 Ibid. at xxiii. members of the official-language minority, should be declared bilingual districts. Moreover, when it came to looking at the language practices in the work place the Commission recommended that in Québec "the principal language of work" should be French. ${ }^{16}$

Similarly, within the federal public service, it recommended the creation of French-language units which would operate primarily in French. In other words, a bilingual public service would depend not on individual bilingualism but institutional bilingualism.

Similar to a conception of bilingualism that rested on two linked linguistic communities was the Commission's conception of biculturalism. Once again, Canada as a whole was bicultural, not individual Canadians. Indeed, individual biculturalism would amount to a person "having two personalities or two styles of living at the same time" a condition that the Commission saw as rare and also quite unhealthy. ${ }^{17}$ Thus, Canada contained "two dominant cultures ... embodied in distinct societies." 18 At the same time, the Commission insisted that these two societies, and cultures, must be open and should welcome newcomers. For this reason, it was very careful to avoid the term "ethnicity." At the same time, if only for tactical reasons, the Commission generally eschewed the term "nation." Thus, Québec was the site of a "distinct society.",

Despite the Commission's insistence that its conception of biculturalism did not involve any notions of ethnicity, the Commission encountered some fierce opposition to biculturalism - primarily from Ukrainian-Canadian leaders who contended that biculturalism relegated them to second-class status. Nonetheless, to the very end of their deliberations, the Commissioners remained firmly committed to their bicultural view of Canada. This is true of Book IV, entitled The Cultural Contribution of the Other Ethnic Groups. ${ }^{20}$ Even commissioner Rudnyckji, who had proposed

\footnotetext{
Canada, Royal Commission on Bilingualism and Biculturalism, Book III: The Work World (Ottawa: Queen's Printer, 1966) at 559.

Supra note 12 at $\mathrm{xxxi}$.

Ibid. at xxxiii.

19 Ibid.

20 Canada, Royal Commission on Bilingualism and Biculturalism, Book IV: The Cultural Contribution of the Other Ethnic Groups (Ottawa: Queen's Printer, 1970).
} 
national status for third languages in particular regions, shared in that consensus. ${ }^{21}$

Having squarely rooted both language and culture with communities, rather than individuals, the Commission offered an expansive interpretation of the other key term in its mandate: "equal partnership." Since "language and cultures are essentially collective phenemona," 22 the Commission argued, equality between language and cultures can exist only if there is equality between the communities in which they are located. Laurendeau wanted to take the Commission one step further: the centrality of Québec to the Francophone community meant that "equal partnership" had to extend to the relationship between Québec and the rest of Canada and thus had to be addressed through change in Canada's political institutions and in their constitutional framework. ${ }^{23}$ But he could not create a consensus on this point within the Commission.

On the other hand, Québec politicians, both in the Québec provincial government and in the federal cabinet itself, did make the argument that, as the site of a "distinct society" or even nation, Québec should assume a different or even special status within Canadian federalism. Prime Minister Pearson himself referred publicly to Québec as "a nation within a nation" 24 and applied broadly a scheme of "opting out," a distinctly Canadian creation whereby Québec could abstain from participating in federal-provincial programs, and even some exclusively federal programs. It would maintain its own programs, while the federal funds that it would otherwise have received would, typically, be secured through enhanced "tax room." Invariably, the same arrangement was made available to the other provinces, and invariably to did not take advantage of it. The New Democratic Party formally approved such arrangements, having already recognized at its founding convention that federalism is "the only system that can assure the joint development of the two nations which originally joined together to

\footnotetext{
21 See Kenneth McRoberts, Misconceiving Canada: The Struggle for National Unity (Don Mills, ON: Oxford University Press, 1997) at 123.

22 Supra note 12 at xxxix-xliii.

23 Supra note 11.

24 Peter C. Newman, The Distemper of Our Times (Toronto: McClelland \& Stewart, 1968) at 320.
}

create Canadian society, as well as the development of other ethic groups in Canada." ${ }^{25}$

Still, however much it eschewed the term "nation," it was the Commission that offered a comprehensive understanding of Canada's underlying social reality. The Commission confronted Canada's underlying linguistic, cultural and national duality in a way that had never been done before - and has never been done since.

However well-founded may have been its vision of Canada, several factors worked against the Commission. Division among the Commissioners over the constitutional question prevented the Commission from ever addressing the matter. Instead, after repeated and inconclusive discussions, the Commission finally ran out of time and ended its operations in January 1971 without a final book spelling out its conclusions. But the Commission was also severely weakened by the sudden death of Laurendeau in 1966. Finally, and most important of all, by 1968 Canadians were presented with another vision of Canada that radically differed from the Commission's yet came from within Québec under the leadership of Pierre Elliott Trudeau. For many Anglophone Canadians, the confrontation with Canada's cultural and linguistic duality, and especially its national duality, had been painful. It collided with the sense of a Canadian nation that had been slowly emerging over the post-war years. With Trudeau they did not have to abandon that idea. In April of 1968, Trudeau won the Liberal Party leadership and became Prime Minister. Three months later, in a federal election, the Trudeau Liberals won a strong parliamentary majority, including the overwhelming majority of Québec seats.

During the 1950s and 1960s, in a remarkable body of essays and pamphlets, Trudeau articulated a quite coherent vision of Canada, as he wanted it to be. A central theme was the rejection of nationalism, indeed the promotion of any collectivity, in favour of the celebration of the individual. The nationalism of the sociological nation was fiercely rejected - it bred intolerance

25 A. Lamoureaux, Le NDP et le Québec, 1958-1985 (Montréal: Les Éditions du Parc, 1985) at 116, translated in McRoberts, supra note 21 at 290. 
and fascism. But in some of his writing Trudeau also took on the nationalism of the state. It too could be irrational and dangerous. The nation and state should be kept separate he argued. Citing Lord Acton, he celebrated the state that contained several nations precisely because the nationalism of such a state would be counter-productive, legitimizing the separate nationalisms of the several nations within the state. In one passage he even talked of Canada as a "multinational state.",

As Prime Minister, Trudeau remained firm in his rejection of the nationalism of the sociological nation, especially if it were the Québec nation. But with time, little remained of his opposition to state nationalism, including that of the Canadian state. Indeed, as Prime Minister he pursued with determination and energy a vision of Canada that was clearly rooted in the idea of a Canadian nation-state. Canada was at last to become one nation. Ultimately, Trudeau was prepared to sacrifice even federalism to that ideal. Language and culture had to be made compatible with the idea of a single nation. In the process, the Commission's understanding of Canada had to go. Bilingualism was radically reconceived. Biculturalism was discarded altogether.

Trudeau was relentless in his struggle to entrench bilingualism and language reform. However, the underlying rationale for his reforms was light years away from that of the Commission. In effect, he defined Canada's linguistic duality in terms which he found more amenable, but which were sociologically problematic.

For Trudeau, language policy, as everything else, had to be framed in terms of the individual. The issue was one of whether Canadians, indeed all Canadians, could choose between the two languages when it came to dealing with the state and whether, as elected representatives, they could use it in the legislature. And the logic applied not just to the federal government, but to all the provincial governments as well. By the same token, a bilingual Canada was one in which

26 Pierre Elliott Trudeau, "New Treason of the Intellectuals" Cité libre, as reproduced in Trudeau, Federalism and the

French Canadians (Toronto: Macmillan, 1968) at 164. individuals were themselves bilingual. Being able to function in both English and French stood as the quintessential Canadian experience. The issue was not one of the health and development of two linguistically-defined communities. As Trudeau declared at the Senate hearings on the Meech Lake Accord,

Bilingualism unites people; dualism divides them. Bilingualism means you can speak to the other; duality means you can live in one language and the rest of Canada will live in another language, and we will all be good friends, which is what Mr. [René] Lévesque always wanted. ${ }^{27}$

Beyond a strong normative commitment to individual rights and individual choice, Trudeau's vision of language and language policy for Canada was also shaped by his political agenda of undermining the claims of Québec nationalism. This too was a compelling reason to conceive language rights on a pan-Canadian basis and pursue a bilingualism that went from "coast to coast." As Trudeau declared in 1968, if minority language rights are entrenched throughout Canada then "the French-Canadian nation" would stretch from Maillardville in B.C. to the Acadian community on the Atlantic Coast:

Once you have done that, Quebec cannot say it alone speaks for French Canadians. ... Mr. Robarts will be speaking for French Canadians in Ontario, Mr. Robichaud will be speaking for French Canadians in New Brunswick, Mr. Thatcher will speak for French Canadians in Saskatchewan, and Mr. Pearson will be speaking for all French Canadians. Nobody will be able to say, "I need more power because I speak for the FrenchCanadian nation." 28

On this basis, the federal government adopted the Official Languages Act in $1969,{ }^{29}$ which outlined a variety of services that Canadians might receive from the federal government wherever

\footnotetext{
27 Senate Debates (30 March 1988) at 2993 (Hon. Pierre E. Trudeau).

28 George Radawanski, Trudeau (Scarborough, ON: Macmillan - NAL, 1978) at 286.

29 S.C. $1968-69$, c. 54
} 
they might be located. The Act also contained provisions for the Official Language Districts that the Commission had contemplated, but these were never put into effect. By the same token, the federal government strongly encouraged all provincial governments to adopt official bilingualism. Thus, the ill-fated Victoria Charter of 1971, a constitutional package that was abandoned because it did not have the approval of Québec, contained a set of language rights which were designed to apply to all provincial governments should they opt for this. The Charter of Rights and Freedoms, ${ }^{30}$ adopted in 1982, guarantees in s. 23 the right of parents whose language is the minority language in a province to have their children educated in that language in public schools. In the early 1970 s, the Trudeau government established a program of transfers to the provincial governments to fund minoritylanguage education.

At the same time, the Trudeau government became heavily involved in encouraging personal bilingualism, in particular by providing extensive funding for second language education. By 19901991, Ottawa was transferring close to $\$ 82$ million to the provincial governments to support secondlanguage education. Central to this effort was the phenomenon of French-language immersion schools. Beyond supporting immersion education, the federal government heavily funded the organization which spearheaded support for immersion schools, Canadian Parents for French.

During the 1970s, the Trudeau government did develop a program of support for Francophone minority communities outside Québec, as well as the Anglophone community of Québec. Yet, when it came to framing the right to minority-language education in the Charter, the government was content to guarantee the right of parents to choose such an education for their children without too much concern over whether minority communities could effectively control the institutions that provided the education.

Ultimately, the federal government's language reforms have been quite successful in terms of the

30 Canadian Charter of Rights and Freedoms, Part I of the Constitution Act, 1982, being Schedule B to the Canada Act 1982 (U.K.), 1982, c. 11 [Charter]. notion of bilingualism that was dear to Trudeau: personal bilingualism. Within the Canadian population as a whole, bilingualism went from 13 percent in 1971 to 17.7 percent in $2001 .^{31}$ Bilingualism is especially high among recent graduates of secondary schools: 14.7 percent among Anglophones outside Québec aged 15-19. ${ }^{32}$ Similarly, among Québec Francophones bilingualism went from 28.7 percent in 1981 to 36.6 percent in $2001 .{ }^{33}$ Of course, these results are based on simple declarations; they are not directly verified.

On the other hand, the Francophone community, which had been the primary concern of the Commission when it examined Canadian bilingualism, has continued its longstanding decline. Within Canada as a whole, the proportion of the population speaking French as its first or primary language has fallen from 25.7 percent in 1971 to 22 percent in $2001 .^{34}$ More to the point, outside Québec the number of individuals using French as their home language has declined from 675,920 in 1971 to 612,895 in $2001 .{ }^{35}$ Indeed, the proportion of people of French mother tongue who do not use it at home has risen from 27 percent in 1971 to 39.4 percent in $2001 .^{36}$

In short, extending the formal right of individuals to choose between languages, and even increasing the number of individuals with a certain knowledge of the second language, do not in themselves assure the survival and development of a community of people who function primarily in that language. By that standard, Canadian bilingualism has declined.

When it came to the Commission's other notion, biculturalism, Trudeau and his associates did not simply redefine it as they did with bilingualism, they supplanted it with something very different. As I have already noted, biculturalism did stir up a certain opposition

\footnotetext{
31 Statistics Canada, Profile of Languages in Canada: English, French and Many Others (2001 Census: analysis series) (Ottawa: Statistics Canada, 2002) at 13, online: Statistics Canada $<$ http://www12.statcan.ca/english/census01/Products/ Analytic/companion/lang/pdf/96F0030XIE2001005.pdf>.

32 Ibid.

33 Ibid.at 14

34 Ibid. at 28.

35 Ibid.

$36 \quad$ Ibid. at 31
} 
among some groups of neither British nor French descent. Yet, it is also clear that Trudeau had his own concerns about biculturalism. Simply put, he feared that, especially as it had been interpreted by the Commission, biculturalism might in fact serve to insinuate the idea of two nations. And to that he was very much opposed. He said as much in a mid-1960s Cité libre article that he co-authored, responding to the Commission's Preliminary Report with a withering critique of its notion of biculturalism. $^{37}$

Instead, the Trudeau government opted for "multiculturalism." In announcing his government's new policy of multiculturalism, in 1971, Trudeau was very clear as to what he was rejecting: "biculturalism does not properly describe our society; multiculturalism is more accurate." ${ }^{38}$ Indeed, even in presenting multiculturalism, Trudeau managed to do so in terms that reflected his own commitment to the individual, dwelling less on the policy's first principle of supporting cultural groups and more on its second principle of assisting members of cultural groups to overcome barriers to their personal participation in Canadian society with the declaration that the policy "is basically the conscious support of individual freedom of choice." 39

Clearly, the vision of multicultural society is a generous one. Canadian multicultural policy has been rightly regarded as an important innovation worthy of study by international scholars and policy-makers. At the same time, it has had its critics. In its early years, Canadian multicultural policy tended to reflect the preoccupations of those who had championed it: largely white, second- and third-generation Canadians of nonBritish, non-French descent. For them, multiculturalism was about preserving cultures through support of folklore and cultural activities. This in turn, engendered a certain public criticism. Subsequently, the policy has focussed more on problems of economic and social discrimination, especially among the growing numbers of "visible minorities." But in the public mind, the original focus - cultural preservation - seems to have

See McRoberts, supra note 21 at 308.

38 House of Commons Debates (8 October 1971) at 8581 (Hon. Pierre E. Trudeau)

39 Ibid. at 8546 (Hon. Pierre E. Trudeau). stuck — and provides a continuing basis for criticism.

As a general statement about Canadian society, whatever the specific policy thrust, multiculturalism does pose some problems. There is the matter of combining bilingualism, or the recognition of two official languages, with the recognition, and indeed promotion, of an infinite number of cultures. First, why should the languages of other cultures also not be recognized and promoted? Indeed, the federal government has been drawn into maintaining programs for the "non-official languages." But, second, does this mean that there is no overarching culture associated with each of the two official languages? Are Francophones and Anglophones indeed no more than groups of individuals who happen to speak different languages - in other words, English-speaking Canadians and French-speaking Canadians? Predictably, the reaction among intellectual and political leaders in Québec, whether Robert Bourassa, Claude Ryan or Guy Rocher, was that the deliberate rejection of biculturalism in favour of multiculturalism did indeed serve to deny the existence of a Francophone culture and society, and that this may have been the primary intent.

In retrospect, one might argue that the notion of a bicultural Canada was doomed, a mere artifact of the 1960s. For most Canadians, biculturalism was inescapably wedded to the idea of two founding peoples, however much the Commission may have wished to present it otherwise. Inevitably, then, biculturalism would be unacceptable in contemporary Canada, given the radical changes that have taken place in its demography thanks to immigration from so many parts of the world. Yet, based upon a projection in time back over several decades, such a line of argument may miss the effect of multicultural policy itself.

The fact of the matter is that, during the 1960s, opposition to biculturalism in favour of multiculturalism was quite concentrated. Ukrainian-Canadian leaders were vigorously opposed but leaders of other groups, such as German-Canadian and Italian-Canadians, were not. It is far from clear that the Trudeau 
government had to reject biculturalism, unless it had reasons of it own for doing so. At the same time, once the federal government did adopt multiculturalism, and proceeded to define Canada in these terms, bilingual but multicultural, then it gave official sanction to the contention that the concept of biculturalism was ethnically based on two founding peoples.

Within a bicultural vision of Canada, the federal government could still have developed its programs to support the cultural activities of a wide of range of groups. The Commission had recommended as much. And there would have been no difficulty in pursuing what has in any event become the primary focus of federal multicultural policy: the elimination of racial and ethnic barriers to mobility.

Indeed, whatever may be the official definition of Canada, the fact remains that it is still profoundly bicultural. Like it or not, the Canadian reality is still one of two societies: an Anglophone one centered outside Québec and a Francophone centered in Québec. However ethnically and racially diverse these two societies may have become, especially the Anglophone one, and however much their cultural frameworks have been adapted through negotiations with new populations, they still persist as distinct entities. In terms of media, popular culture and the structures of civil society, Canada arguably has become even more bicultural. Anglophone Canadians may denote their society as simply "Canada," rather than English Canada or even English-speaking Canada; Francophones in Québec may see their society as simply "Québec." The fact remains that Canada continues to house two overarching cultures and societies.

Finally, when it came to the notion that there should be political recognition and accommodation of the nationalism of nations within Canada, the Trudeau government's attitude was straightforward - in terms of Canada's political institutions there could be only one nation, the Canadian nation. In particular, there was no tolerance for the Québec government's contention that within its jurisdictions it represented a nation, whether it be the FrenchCanadian nation or the Québec nation. This was, of course, the traditional understanding of the role of the Québec government. Back at Confederation, French-Canadian leaders saw the purpose of the Québec government in precisely these terms, as is evidenced by the quotations from la Minerve. It was for this reason that they had insisted that the new British North America had to be federal. This understanding of the role of the Québec government was compatible with the notion of a Canada based on a compact. It had no place in a Canada that was a nation-state.

Indeed, Trudeau's personal determination to remake Canada as a nation-state was so strong that he was prepared to discard even the principle of federalism itself. In a speech of major portent that Trudeau made to Parliament in early 1980, he declared that

We [the Members of Parliament] are the only group of men and women in this country who can speak for every Canadian. We are the only group, the only assembly in this country, which can speak for the whole nation, which can express the national will and the national interest. $^{40}$

He even went so far as to proclaim it a good thing that the Fathers of Confederation had given the powers of disallowance and reservation to the federal government so that it could intervene against a province that was acting "contrary to the national interest." ${ }^{41}$ After all, "when there is a conflict of interest, not of laws, which will be judged by the courts, the citizens must be convinced that there is a national government which will speak for the national interest and will ensure that it does prevail." ${ }^{42}$ And he repeatedly used the same reasoning to justify repatriating the constitution without the consent of the Québec provincial legislature - or indeed without a majority of all the provinces.

Within such an understanding of Canada there was, of course, no reason why the federal government should not seek to patriate the constitution, augmented by a bill of rights, without

\footnotetext{
40 House of Commons Debates (15 April 1980) at 32 (Hon. Pierre E. Trudeau).

${ }^{41}$ Ibid. at 33 (Hon. Pierre E. Trudeau).

42 Ibid.
} 
the approval of the provincial governments, as the Trudeau government threatened to do, or over the objection of Québec alone, as it did do.

Thanks in part to the Trudeau constitutional reforms of 1982, the discourse of Canada as a nation-state has become dominant. It may be systematically rejected in Québec, by federalists and sovereigntists alike, but it has the overwhelming support of Canadians in the rest of the country.

The fact of the matter is that this notion of a Canadian nation-state has had a powerful appeal to English-speaking Canadians. By the midtwentieth century, the old idea of Canada as a British nation, integrally linked to the Commonwealth if not the Empire, had lost all credibility. The post-war rise of the United States to world hegemony had sharpened concern over American economic and cultural domination. As Anglophone Canadians cast about for a new conception of Canada, the Trudeau vision of a bilingual, multicultural nation had much to commend it. Bilingualism and multiculturalism distinguished Canada from its "melting pot" southern neighbour - at least at the level of national myths. And it promised to integrate Québec Francophones with the rest of Canada to form a single nation.

It may be that the notion of a "bilingual nation" is inherently problematic. After all, the concept of nation stresses commonality and shared experience but differences in language imply quite the opposite. Nor can they be readily resolved through personal bilingualism. To define bilingualism as the quintessential national experience would be to restrict it to a restricted stratum of the nation. Beyond that, as the Commission recognized, two or more languages within the same state will tend to be concentrated in territorially defined centres of dominance. Indeed, their survival depends on such segregation. Yet, this requirement of territorial division is bound to pose problems for national unity. Beyond fostering attachments to regions rather than the nation as a whole, it can hinder mobility within the nation. Nonetheless, Canada's linguistic duality was too important to be denied.
If Canada is to be a nation, then it would have to be as a bilingual one.

Yet, while the dominant Canadian political discourse has moved to the nation-state model, the underlying social and cultural reality of Canada has, if anything, moved in the opposite direction. While personal bilingualism may have increased, thanks in particular to the federal government's support French immersion, Canada's two linguistic communities have in fact become more territorially distinct. As measured by the language normally used at home, French speakers' share of the total population outside Québec declined from 4.4 percent in 1971 to 2.7 percent in $2001 .^{43}$ They now represent less than 3 percent of the populations of all provinces but Québec and New Brunswick. ${ }^{44}$ Paralleling the decline of the Francophone minorities has been the decline of the single Anglophone minority, that of Québec. From 14.7 percent of Québec's population in 1971, Anglophones had fallen to 10.5 percent in $2001 .{ }^{45}$ Here, out migration has been the primary cause.

By the same token, while Anglophone Canadians have become firmly wedded to the idea of a Canadian nation, Québec Francophones have become more and more attached to the notion of a Québec one. By 1990, the overwhelming majority of Québec Francophones, 59 percent, identified themselves as "Québécois"; in 1970, only 21 percent had done so. ${ }^{46}$ And the proportion seeing themselves as Canadians had fallen to 9 percent, from 34 percent in $1970 .^{47}$

Beyond that, over the last two decades a new idea of nationhood has emerged, that of the "First Nations," among Canada's Aboriginal Peoples. This has served to raise in a new context the very same issues of accommodating national identities and national needs within a common state. Once again, the ideal of a Canadian nation-state has been placed in question.

\footnotetext{
Supra note 31 at 28.

Ibid.

$45 \quad$ Ibid. at 27.

46 Maurice Pinard, "The Dramatic Reemergence of the Quebec Independence Movement" (1992) 45:2 Journal of International Affairs 471, at Table 3.

47 “Portrait des Québécois" L'actualité 16:1 (January 1991) 13 at $13-16$.
} 
In short, over the last three decades, Canada has been more and more caught up in the contradiction between the discourse and political institutions of a nation-state and the cultural and social reality of a multi-national state.

Out of this contradiction came the debacle of the Meech Lake Accord. A modest set of changes designed to secure Québec's adherence to the new Canadian constitution, the Accord mainly would have formalized practices and arrangements there were already in effect. But it also contained a clause declaring the Québec constituted a "distinct society" - the very phrase that the Commission on Bilingualism and Biculturalism had formulated. But in the Canada of the late 1980s, this term was no longer acceptable. It conflicted with the new idea of a Canadian nation-state that most Anglophone Canadians had come to accept - and they massively rejected the Accord. The collapse of the Meech Lake Accord in turn produced a profound reaction among Québec Francophones, who saw English-Canadian rejection of the Accord as a rejection of their own existence as a distinct collectivity within Canada. As a result, support for Québec sovereignty surged dramatically, reaching over 60 percent of all Québeckers. This profound sense of rejection in turn largely explains how in 1995 the Québec government came so incredibly close to securing a "Yes" vote in its referendum on Québec sovereignty.

So, Canada is more than ever a multi-national state in terms of its underlying social and cultural reality. Yet, it is also more than ever a nationstate in its dominant discourse and political institutions. As a result of this contradiction, political debate in Canada remains fixated on Québec sovereignty or independence - the political option that is clearly desired by neither the majority of Québeckers nor the majority of the rest of Canada. Nor are First Nations seeking full sovereignty.

The fact remains that in the 1960 s, and over subsequent decades, Canada has produced some very promising theorizations about accommodating linguistic and cultural diversity. As well, it has experimented with some innovative political practices such as asymmetrical federalism. Perhaps Canadians might yet abandon the illusions of the nation-state.

\section{Kenneth McRoberts}

Principal and Professor of Political Science Glendon College, York University 